\title{
SURVIVAL OF Liparis loeselii (L.) AS AN EARLY SUCCESSIONAL SPECIES IN ENGURE REGION DESCRIBED BASED ON ECOLOGICAL PECULIARITIES DURING THE ANNUAL CYCLE
}

\author{
Daina Roze ${ }^{\star, * \star \#}$, Gunta Jakobsone $e^{\star \star *}$, Dace Megre ${ }^{\star \star, * \star *}$, Inta Belogrudova ${ }^{\star \star}$, \\ and Amanda Karlovska ${ }^{\star \star \star \star}$ \\ * Daugavpils University, Vienības iela 13, Daugavpils, LV-5401, LATVIA; \\ daina.roze@gmail.com \\ \# Corresponding author \\ ** National Botanic Garden, Latvia, Miera iela 1, Salaspils, LV-2169, LATVIA \\ ${ }^{* \star *}$ Faculty of Biology, University of Latvia, Kronvalda bulv. 4, Rĩga, LV-1586, LATVIA \\ ${ }^{* * \star *}$ Latvia University of Agriculture, Lielā iela 2, Jelgava, LV-3001, LATVIA
}

Communicated by Viesturs Melecis

\begin{abstract}
We present some results of a six-year (2008-2013) study in two localities of Liparis loeselii (L.) Rich. near Lake Engure. The annual cycle of L. loeselii, an early successional species, may indicate its potential survival in its typical wet habitat with fluctuating levels of water. Flowering of $\mathrm{L}$. loeselii usually begins in the first decade of June and lasts for several weeks. If the initiation of development was delayed, leaves and inflorescence started to grow almost simultaneously. Development of the first fruit began during flowering and continued to August. Ripening of fruit and seeds occurred in September-October, and they were dispersed mostly by melt water of snow in spring, which is very important for populations in sites overgrowing with perennial herbs. The previous season capsules of $\mathrm{L}$. loeselii remained till the middle of the next growing season; a part of the seeds remained in capsules and less than $1 \%$ of seeds had viable embryos. This may increase the survival potential of the population. The studies of herbarium records of $\mathrm{L}$. loeselii in the area of Lake Engure showed that the annual cycles of $\mathrm{L}$. loeselii have been similar and that the species has not responded drastically to climate change.
\end{abstract}

Key words: wet habitats, phenology, herbarium, embryo viability, water fluctuating.

\section{INTRODUCTION}

Lake Engure is located on the western coast of the Gulf of Riga. It formed about 4000 years ago. The lake area is approximately $45 \mathrm{~km}^{2}$ and average depth is less than $1 \mathrm{~m}$ (Viksne, 1997; 2000). The investigation of the flora of the Lake Engure started at the beginning of $20^{\text {th }}$ century and continued with more or less similar intensity ever since. Lake Engure is one of the richest areas in vascular plant species and communities in Latvia (Kupffer, 1925; Pakalne, 1994; Gavrilova and Baronina, 2000; Laime, 2000; Kabucis et al., 2004; Gavrilova et al., 2005; Salmina, 2009; Zviedre and Grīnberga, 2012). A total of 844 vascular plant species have been recorded in the Lake Engure Nature Park, including about 81 endangered species (Gavrilova and Baronina, 2000). Overgrowth with emergent macrophytes has threatened the biological diversity of the Lake Engure and eutrophication of the lake is reflected in an increase of macrophyte biomass (Sprinǵe et al., 2000; Vīksne, 2000; Brižs, 2011).
L. loeselii is a declining orchid species throughout its distribution range in the temperate zone in Europe; it is sporadic in the submeridional zone, also eastwards in the temperate zone to central Siberia and in temperate and boreal northern America, except Alaska (Moore, 1980; Buttler, 1991). The broad geographic distribution of the species indicates its adaptability. Although $L$. loeselii in its range occurs in different moist habitats: wet and sandy lakeshores un meadows, fens, ditches and old fields, abandoned peat excavations, abandoned gravel pits, forested wetlands, it prefers specific microhabitats with moist, bare ground with little competition from other plants, and gradually disappears as sod develops (Case, 1987; Wheeler et al., 1998; McMaster, 2001). It should be noted that not only endemic orchid species in Europe are threatened, but also species with a relatively large area of distribution. L. loeseli is an example of one of these species (Kull, 2013). L. loeselii is included in the third (Rare) threatened category in the Red Data Book of Latvia (Andrushaitis, 2003). In Europe, L. loeselii is a 
rare and endangered species listed in Annex II of the European Directive 92/43/EEC.

In Latvia, L. loeselii occurs as solitary individuals and in groups, where it is close to the northern limit of its distribution range (Kuusk et al., 2003; Cepurìte, 2005; Kull and Hutchings, 2006). Species can be found throughout the whole territory, mostly in calcareous wetlands, and it is characteristic of plant communities in calcareous fens of the Scheuchzerio-Caricetea fuscae class and the Caricion davallianae order (Pakalne, 2008). The vegetation in the area of Lake Engure is dominated by the plant communities Schoenetum ferruginei and Sesleria caerulea-Pinus sylvestris comm. The vegetation is highly dynamic and plant community composition is changing. The current vegetation development process is characterized by expansion of Phragmites australis (Cav.) Trin. ex Steud., Molinia caerulea (L.) Moench and Calamagrostis epigeios ((L.) Roth (Laiviňš et al., 2012). It is known that L. loeselii has been growing in this area for more than 100 years, which has been confirmed by herbarium records since 1906 on the east shore of Lake Engure. The aim of our study was to determine how L. loeselii, as an early successional species, has survived in this area. We studied the biology of L. loeselii as a wetland plant (annual cycle, root anatomy, biometric study of leaves and embryo viability test) and monitored influence of environmental factors in localities (projective cover, water level and potential pollinators) in order to explain the survival of the population.

\section{MATERIALS AND METHODS}

Species description. The fen orchid (L. loeselii) is a small perennial herb. The height of plants is $4-30 \mathrm{~cm}$, varying with habitat. The two glossy basal leaves are yellow green, oblong-elliptical to broadly elliptical, from 3 to $22 \mathrm{~cm}$ long and $1.0-6.5 \mathrm{~cm}$ wide, acute or obtuse at apex with a distinct keel. The pseudobulb is formed by swelling of the lowest part of the aerial stem and is connected to the epiphytic life form. A new shoot emerges from the pseudobulb in late May or early June. The number of white to yellowish green flowers varies between 2 and 20. The time of flowering is from June to July in Latvia (Cepurite, 2005) whereas in other regions — from May to August (Feodorov, 1976; Scoggan, 1978; Moore, 1980; Kuusk et al., 2003; Sell and Murrell, 1996). Fruiting capsules are larger than the flowers. L. loeselii, like most orchids, produces large numbers of dust like seeds (Rasmussen, 1995).

Methods. Two localities (Orchid Trail of the Engure Nature Park and the eastern shore of the Lake Engure, by Lepste) were monitored three to four times each growing season during a six-year period - 2008-2013. The vegetation was described using the Braun-Blanquet method (Ellenberg, 1996). The taxa were named in accordance with the Flora of Latvian Vascular Plants (Gavrilova and Šulcs, 1999) and List of Bryophytes of Latvia (Ābolin,a, 2001). The Manual of European Union Protected Habitats in Latvia (Auniňš, 2010) was used to classify habitats. The coordinates of $L$. loeselii localities were determined with a Magellan Explorist 210 GPS receiver. Photos were taken for recording of the plants. On the eastern shore of Lake Engure by Lepste, a permanent sample plot $5.8 \times 3.3 \mathrm{~m}\left(19 \mathrm{~m}^{2}\right)$ was established. The water level $(\mathrm{cm})$ in June was measured in ten replicates every year.

The annual cycle of the L. loeselii was subdivided into three clearly distinguishable phenological developmental phases:

1) flowering,

2) flowering and fruit development,

3) ripening of fruit and seed.

Herbaria of 83 specimens of L. loeselii collected in the area of Lake Engure from 1906 to 1995 (LATV-Herbarium of Institute of Biology University of Latvia, RIG-Herbarium of Latvian University) were examined. In the herbaria, different phases of flowering and flowering and fruit development were represented.

For anatomical analysis roots of three L. loeselii plants from the locality on the Orchid Trail in Engure were collected in June 2012. Samples were fixed in FAA solution [37\% formaldehyde /glacial acetic acid $195 \%$ ethanol/distilled water (10:5:50:35, v/v/v/v)]. After fixation, samples were dehydrated in an ethanol-tert-butyl alcohol series, and embedded in Histowax (Ruzin, 1999). Serial $40 \mu \mathrm{m}$ cross sections were prepared using a rotary microtome (LEICA RM2145), deparaffinized in a xylol-ethanol series, stained with astra blue-safranin (Braune et al., 1999), dehydrated in an ethanol-xylol series and mounted on glass slides in Canada balsam. Cross sections of plant roots were examined and photographed using a Leica DM5500B light microscope equipped with a digital camera Leica DFC490.

Biometric study of L. loeselii was performed for both populations from 2009 to 2013. Leaf blade lengths and widths were measured and their ratios were calculated from 16 to 60 leaves (8 to 30 plants) (Fig. 1).

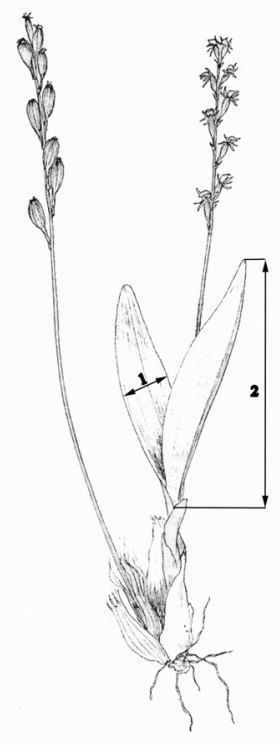

Fig. 1. Measurement of L. loeselii leaf blade length (2) and width (1). 
In the locality on the eastern shore of the Lake Engure by Lepste, the study was made of potential pollinators during two weeks in the second part of June (14-28 June 2009; 12-21 June 2010) using Malaise-type traps, and coloured pan traps. Malaise-type traps were placed above the L. loeselii, so that the inflorescence halfway located inside the trap and control traps were placed beside to these plants. A coloured pan trap was located at each Malaise-type trap. Each variant of traps was used in ten replicates. Insect specimens were fixed in $80 \%$ ethanol and identified by family.

Seeds collected in 2009 and 2013 were tested for embryo viability. Capsules from 8-16 plants (depending on population size) were collected on 25 August 2009, and on $26 \mathrm{Au}-$ gust and 8 November in 2013. Over-wintered capsules were sampled on 11 July 2012. After collecting, the packets with capsules were placed in a refrigerator $\left(4{ }^{\circ} \mathrm{C}\right)$ and the tests were made one to two days afterwards. Seeds from one or two capsules from each plant were strewed onto filter-paper discs, mixed and evenly aligned. Embryo viability was determined using 1\% 2, 3, 5-triphenyltetrazolium chloride (TTC) test (modified Ramsey and Dixon, 2003). The seed-coats were decolourised with commercial chlorine-based agent ACE: distilled water (1:1) for 8 minutes. After sufficient rinsing in distilled water, the packets with seeds were left in the last portion of chlorine-free distilled sterile water for 24 hours. The packets were then blotted with filter-paper slices and immersed in 1\% TTC $(\mathrm{pH} 7)$ for 24 hours at $30{ }^{\circ} \mathrm{C}$ in the dark. After exposition in TTC, we repeated the washing procedure and placed the unwrapped packets in Petri plates. The viable embryos stained red. Three sample-discs from each habitat were tested. The counting was carried out in five different fields of vision in the sample-disc using a stereoscopic microscope MБC-1 with 16-multiplied extension.

Statistical analyses were performed using Statgraphics Centurion. All data are presented as means with standard errors. Data were tested for normality using the Chi-Square test. Significant differences between groups were assessed using Tukey test. Correlations between leaf length/width ratio and water level were determined by simple (paired) regression analysis.

\section{RESULTS}

In 2008, the locality of L. loeselii on the eastern shore of the Lake Engure by Lepste $\left(57^{\circ} 17^{\prime} 175 ; 2^{\circ} 08^{\prime}\right.$ 990) was classified as the EC protected habitat 7210 Calcareous fens with Cladium mariscus and species of the Caricion davallianae. Other species in this habitat were Carex elata All., Carex lasiocarpa Ehrh., Cladium mariscus (L.) Pohl, Ph. australis, Schoenus ferrugineus L., Utricularia intermedia Hayne. and in the bryophyte layer - Cinclidium stygium SW. During the six-year period, cover of perennial plants increased by $40 \%$ (from $50 \%$ in 2008 to $90 \%$ in 2013) in this locality. The cover of $P$. australis increased from $5 \%$ to
$15 \%$ and with $C$. maricus from $30 \%$ to $70 \%$. The total cover of other species decreased from $10 \%$ to $5 \%$.

On the Orchid Trail in Engure $\left(57^{\circ} 15^{\prime} 813 ; 2^{\circ} 08^{\prime}\right.$ 659) $L$ loeselii occurred in 2008 in the protected EC habitat 7230 Alkaline fens. L. loeselii occurred together with C. mariscus Ph. australis, Potentilla erecta, Primula farinosa L., S. ferrugineus, and $U$. intermedia, and in the bryophyte layer Campylium stellatum (Hedw.) J. Lange et C. Jens. During the six-year period, the cover of perennial plants increased by $65 \%$ (from $30 \%$ in 2008 to $95 \%$ in 2013 ) in this locality. The cover of $C$. mariscus increased from $15 \%$ to $70 \%$ and of $P$. australis from $1 \%$ to $10 \%$. The total cover of other species decreased from $5 \%$ to $1 \%$. In 2013, only S. ferrugineus and $L$. loeselii occurred and $P$. farinosa, $P$. erecta, and $U$. intermedia had disappeared. As a result of overgrowth with $C$. mariscus the habitat 7230 Alkaline fens (Orchid Trail in Engure) had transformed to habitat 7210 Calcareous fens with Cladium mariscus and species of the Caricion davallianae.

Herbarium specimens of $L$. loeselii collected along the shore of Lake Engure showed that the annual cycle of $L$. loeselii was similar to that observed in 2008-2013 (Table 1 ). The flowering of $L$. loeselii usually began in the first decade of June and lasted for several weeks. The leaves and inflorescence started to grow almost simultaneously in years when the initiation of development of L. loeselii was delayed, such as in 2010. Peak flowering occurred in the second and third decade of June. Development of the first fruit began during flowering and continued until August. Ripen-

Table 1

ANNUAL CYCLE OF L. loeselii SHOWING CURRENT DATE OF PHENOLOGICAL DEVELOPMENT PHASE*

\begin{tabular}{|c|c|c|c|}
\hline $\begin{array}{c}\text { Phenological de- } \\
\text { velopmental phase }\end{array}$ & Flowering & $\begin{array}{l}\text { Flowering and de- } \\
\text { velopment of fruit }\end{array}$ & $\begin{array}{c}\text { Ripening of fruit } \\
\text { and seed }\end{array}$ \\
\hline \multicolumn{4}{|c|}{ Herbarium } \\
\hline 1906 & 03.06 & - & - \\
\hline 1958 & - & 02.07 & - \\
\hline 1964 & - & 20.06 & - \\
\hline 1975 & 25.06 & - & - \\
\hline 1976 & - & 28.07 & - \\
\hline 1984 & - & 10.07 & - \\
\hline 1987 & $11.06-17.06$ & 06.07 & - \\
\hline 1989 & - & 13.07 & - \\
\hline 1992 & - & 02.07 & - \\
\hline 1995 & 19.06 & - & - \\
\hline \multicolumn{4}{|c|}{ Engure } \\
\hline 2008 & 10.06 & 07.07 & 10.08 \\
\hline 2009 & 14.06 & 13.07 & 15.08 \\
\hline 2010 & 09.06 & 01.07 & $11.08 ; 31.08$ \\
\hline 2011 & 14.06 & 07.07 & 15.08 \\
\hline 2012 & 15.06 & $26.06 ; 11.07$ & - \\
\hline 2013 & 14.06 & 27.06 & $26.08 ; 08.11$ \\
\hline
\end{tabular}

* Based on monitoring data from 2008 to 2013 and herbarium data from 1906 to 1995 


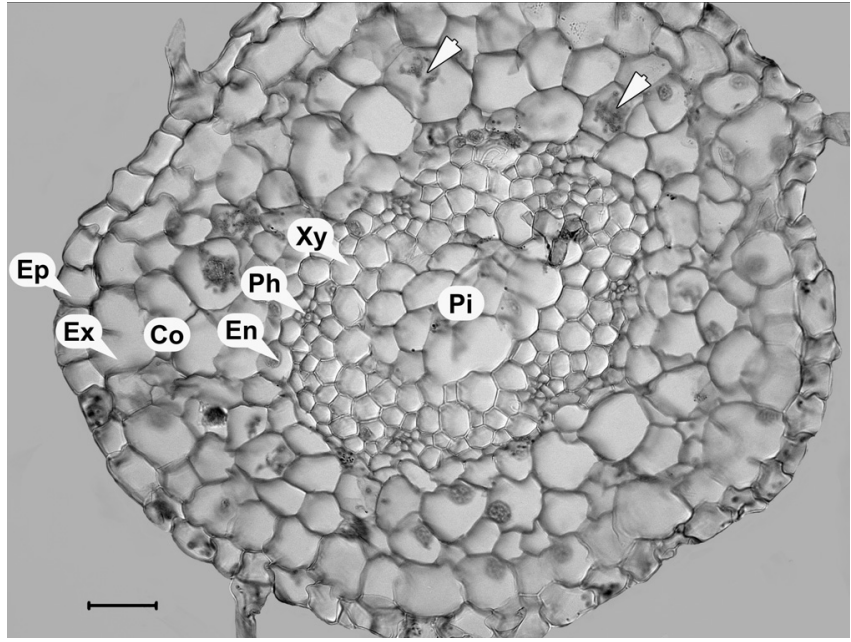

Fig. 2. Cros-section of Liparis loeselii root from the Orchid Trail in Engure illustrating general structures of root anatomy and fungal hyphae in cortical cells (white arrows). Ep-epidermis, Ex-exodermis, Co-cortex, En-endodermis, Xy-xylem, Ph-phloem, Pi-pith. Scale bar $50 \mu \mathrm{m}$.

ing of fruit (capsules) and seeds occurred in September-October.

As to root anatomy, epidermis was simple, non-velamentous (Fig. 2); exodermis consisted of one cell layer. The cortical tissue generally consisted of 2-4 layers. Cortex cells were thin-walled, circular to oval with triangular or quadrangular intercellular spaces. Fungal hyphae were detected in cortex cells. Endodermis consisted of one cell layer. Vascular cylinder polyarch-phloem clusters were oval alternate with xylem areas. Pith consisted of centrally located thin-walled cells.

The ratio between leaf length and width was between $2.76 \pm$ 0.06 and $3.09 \pm 0.05$ for plants from the Orchid Trail, and $2.95 \pm 0.08$ and $3.88 \pm 0.10$ for those from the eastern shore of the Lake Engure by Lepste (Fig. 3). There was a signifi-

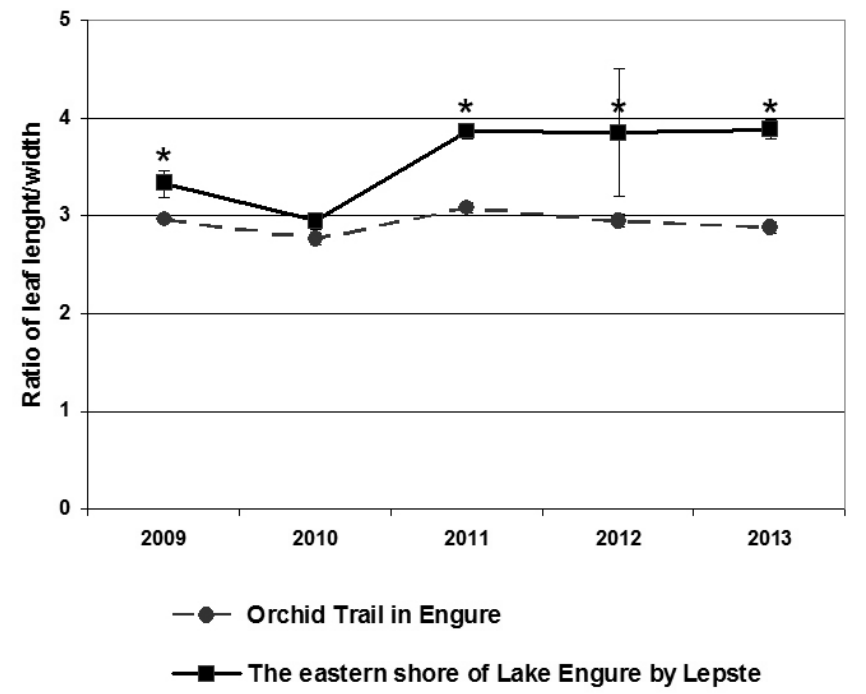

Fig. 3. Liparis loeselii leaf length/width ratio in the localities of the Orchid Trail in Engure and eastern shore of the Lake Engure by Lepste from 2009 to 2013. Asterisk (*) indicates a significant difference between values (mean \pm standard error) in the localities at $P<0.05$ cant difference $(P<0.05)$ in $L$. loeselii leaf length and width ratio between localities yearly, excepting in 2010. In June, on the eastern shore of Lake Engure by Lepste, the water level fluctuated between $32.0 \pm 2.8 \mathrm{~cm}$ (2010) and $15.0 \pm 4.5 \mathrm{~cm}$ (2013), and near the Orchid Trail from $27.0 \pm$ $3.3 \mathrm{~cm} \mathrm{(2010)}$ to $3.0 \pm 1.0 \mathrm{~cm}$ (2013) (Fig. 4). Fluctuation of the water level in June was related to leaf length and width ratio. On the eastern shore of Lake Engure by Lepste leaf ratio was negatively correlated with the water level $(\mathrm{R}=-0.94, P<0.05)$ but a significant correlation was not observed for plants from the Orchid Trail in Engure.

In the permanent sample plot on the eastern shore of the Lake Engure by Lepste, the population decreased from 8 non-flowering individuals and 14 flowering individuals in 2008 to two flowering individuals in 2013 (Fig. 5). The number of plants in the sample plot during these years (from 2008 to 2013) was reduced by $82 \%$. During 2008-2012, 62-67 \% of flowers formed capsules. In 2013, capsules were formed by all plants.

Insects collected in Malaises-type traps belonged to ten families. The dominating insect family were Chironomidae (68 in 2009, control - 58; 84 in 2010, control - 63); insects of this family do not feed and they live only for a few days. In the coloured pan traps, the dominating family was Syrphidae (34 individuals in 2009 and 74 individuals in 2010). Insects described as orchid pollinators (Hymenoptera and Sarcophagidae) were found only in coloured pan traps: four individuals in 2009 and one in 2010 from Hymenoptera, and eight blowflies (Sarcophagidae) in 2010.

TTC test results in late August showed $22.5 \pm 2.5 \%$ viable embryos of. L. loeselii collected from the Orchid Trail in Engure, and $23.3 \pm 13.6 \%$ of those from the eastern shore of Engure by Lepste in 2009; in 2013 correspondingly $10.13 \pm$ $2.43 \%$ and $0.33 \pm 0.33 \%$. The seeds collected in November $8^{\text {th }}, 2013$ in both localities showed $25.5 \pm 3.1 \%$ viable embryos of. L. loeselii from the Orchid Trail in Engure and $16.5 \pm 2.8 \%$ in those from the eastern shore of Engure by

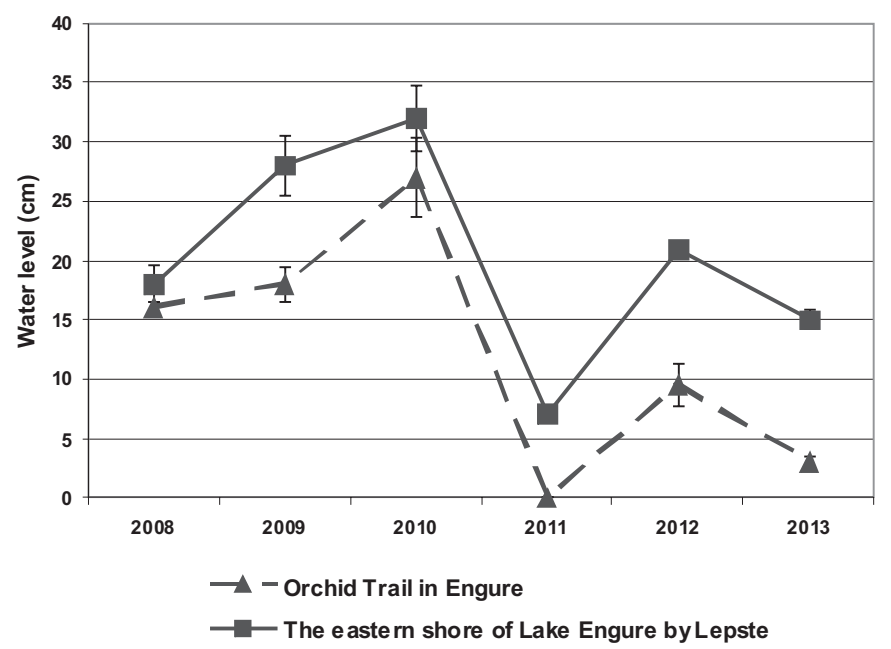

Fig. 4. Water level changes in the localities of the Orchid Trail in Engure and eastern shore of the Lake Engure by Lepste in June from 2008 to 2013.

Values ( \pm standard error) are means of 10 measurements. 


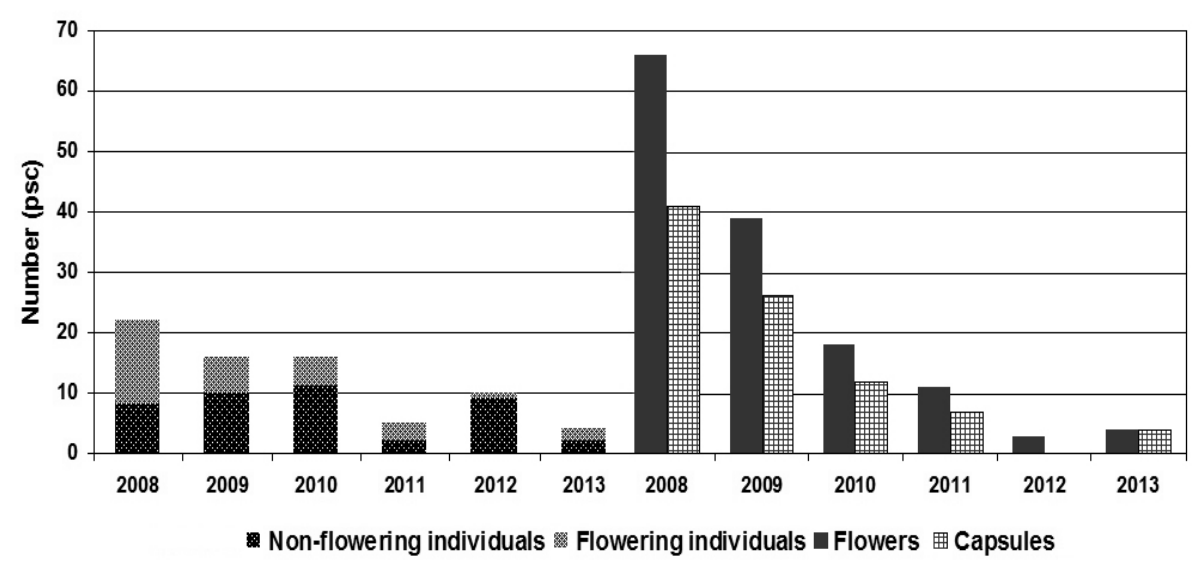

Fig. 5. Changes of Liparis loeselii population dynamics and reproductive success (flower and fruit production) in the locality on the eastern shore of Lake Engure by Lepste in the years 2008-2013
Lepste. The previous season capsules of L. loeselii remained till middle of next growing season and a part of the seeds remained in capsules, although less than $1 \%$ of seeds had viable embryos.

\section{DISCUSSION}

The timing of phenological events is important for management of natural resources, as the phenology of plants shows periodic plant cycle events and how these are influenced by seasonal and inter-annual variations in climate. Particularly important are the dates of first occurrence of biological events in annual cycles, such as leafing, flowering and maturation of seeds (Niklass, 1997; Lamber et al., 2008).

New roots of $L$. loeselii develop in spring (Rasmussen, 1995). Despite the fact that $L$. loeselii grows in wetland habitats, the root cortex of L. loeselii does not have large intercellular air spaces (aerenchyma) (Fig. 3), which are characteristic of plants in these habitats. It is known that in this case, flood tolerance must be very dependent on shallow rooting or indicate a normal preference for the more aerated or flushed wetland habitats (Justin and Armstrong, 1987). It is more likely that short duration flood tolerance of $L$. loeselii is dependent on shallow rooting (surface or sub-surface roots are above the soil or in the oxygenated portion of the soil profile) (Cronk and Fennessy, 2001) and it requires habitats with sparse vegetation in places where no other large herbaceous vegetation is present. L. loeselii tends to grow rooted in the substrate surface, similar as other members of the genus Liparis (Wheeler et al., 1998). Root location in substrate upper layers or in the moss (C. stygium, $C$. stellatum) layer, or in the root network of $S$. ferrugineus, in habitats with sparse vegetation, promotes availability of oxygen and survival during short flood periods.

New leaves emerge from a pseudobulb that overwinters just beneath the substrate surface, and the inflorescence develops later (Roze et al., 2013b). In 2012, in both localities new leaves and inflorescence began to grow almost simultaneously after high water levels that delayed the initiation of development.
Leaves of plants are sensitive to environmental changes and may exhibit phenotypic plasticity as a response to abiotic stress (Niklas, 1997; Pianka, 2000). L. loeselii has been an interesting subject for studies of leaf morphology, because it occurs in habitats with fluctuating water level. The water level fluctuates to a greater extent on the eastern shore of the Lake Engure by Lepste, compared to that near the Orchid Trail (Fig. 2). This might explain the significant difference in leaf ratio between localities, as well as the negative correlation between leaf ratio and water level at the locality on the eastern shore of the Lake Engure by Lepste. When the water level was high, as in 2010, the leaf ratio did not significantly differ between localities. The species is dependent on a constant hydrological regime. When temporary changes in water regime, such as flooding or a drop in the water level occurs, the species does not flower and can survive in a vegetative stage. When the changes are permanent, the species disappears after three or four years. The number of individuals decreases after even short-term flooding (Jersakova and Kinndlman, 2004). Our studies in the permanent sample plot at the eastern shore of Lake Engure by Lepste showed that the population size decreased (Fig. 5).

Very little is known about the pollination mechanism of $L$. loeselii. The species is capable of self-pollination by rain drops (Catling, 1980; van der Cingel, 2001). However, it is known that cross-pollination by insects occurs (Buttler, 1991; Magrath, 2002; Cepurīte, 2005). Blowflies (Sarcophagidae) and possibly other flies are known as pollinators for other species of the genus Liparis - Liparis lilifolia (L.) Rich. ex Lindley. It is believed that the species have a putrescible corpse smell that is not detected by humans, but which attracts blowflies. L. lilifolia may produce a fetid smell similar to that of rotting flesh, which can attract pollinators. It should be noted that the purple coloration and striations of the lip in this species may be a form of mimicry. The colouration may have evolved to attract insects interested in feeding or reproducing in carrion (Mattrick, 2004).

In our study, potential pollinators were not observed, although blowflies were detected in the studied habitats. $L$. loselii flowers are yellow-green and lack obvious coloura- 
tion, in contrast to L. lilifolia. Possibly, the lack of a detectable floral fragrance of flowers and nectar production (Pillon et al., 2007; Rolfsmeier, 2007) are replaced by other aggregating mechanisms of the pollinators. However, the finding of blowflies suggests a need for more research. It is possible that in the populations of L. loeselii at Lake Engure, a rain-mediated pollination mechanism may provide a strategy for reproductive assurance by promoting self-pollination under conditions when pollinators are infrequent.

L. loeselii is a serial species of early successional communities (Jones, 1998; Wheeler et al., 1998). It grows in habitats with sparse vegetation on calcareous wet soils where competition with large herbaceous plants is lacking (McMaster, 2001). Lake Engure is a shallow lake located in the Coastal Lowland. A high concentration of calcium and relatively low water levels are important factors for growth and spread of $C$. mariscus. A temperature from $-4{ }^{\circ} \mathrm{C}$ to $-8{ }^{\circ} \mathrm{C}$ during winter and from $16{ }^{\circ} \mathrm{C}$ to $18{ }^{\circ} \mathrm{C}$ during summer promotes the growth of this species (Salmina, 2006). Long-term mean temperatures at the Mèrsrags meteorological station (Kurpniece et al., 2013) indicate favourable conditions for the growth of $C$. mariscus. Our observations showed that during the six-year observation period, cover of perennial plants increased by $40 \%$ (from $50 \%$ in 2008 to $90 \%$ in 2013 ) in the locality on the eastern shore of Lake Engure by Lepste and by $65 \%$ (from $30 \%$ in 2008 to $95 \%$ in 2013) in the locality on the Orchid Trail in Engure. C. mariscus on the Orchid Trail in Engure and C. mariscus and P. australis on the eastern shore of Lake Engure by Lepste pose potential threats to L. loeselii, particularly if the sites become drier or if siltation or nutrient accumulation becomes a problem. This phenomenon has been observed in the locality on the Orchid Trail in Engure (Roze et al., 2011).

It is known that the competition from fen plants near suitable sites may also act as a barrier to dispersal, as many of the seeds are likely to land in places with persistent vegetation. In general, the large number of seeds produced offsets losses from insect predation and dispersal to unsuitable habitats (Rasmussen, 1995). As for most orchids, L. loeselii seeds are minute (dust like) and produced in great number, probably several thousands per fruit. In North America, seeds of L. loeselii ripen in September-October and capsules of this species tend to stay closed until autumn or through the winter, opening in response to increased atmospheric moisture or being weighted down by snow cover (Rolfsmeier, 2007). Also in Latvia seeds of L. loeselii ripen in September-October (Roze et al., 2013b). This was confirmed by results of the TTC test of seed viability. Seed viability differed between month when collected: $25.5 \%$ in November and $10.13 \%$ in August at the Orchid Trail, compared with $16.5 . \%$ and $0.33 \%$, respectively on the eastern shore of Lake Engure by Lepste. Reduced seed viability in August may be associated with sensitivity of immature seeds to mechanical effects during the test.

The seeds of Liparis are highly mobile and are known to travel long distances carried by air currents (Arditti, 1992;
Rasmussen, 1995; McMaster, 2001). C. Mattrick (2004) noted that seasonally high winds can remove the seed from capsules of L. lilifolia in autumn, which are dispersed by snowmelt water in spring. We observed that capsules of $L$. loeselii can overwinter under snow and are dispersed by wind and melt water of snow March-April (Roze et al., 2013b). Snow melting in Engure occurs in mid March (Kḷaviňš et al., 2013). At that time, temperature of the substrate is low and the surrounding vegetation has not started growth, thereby allowing seeds of L. loeselii to disperse better. Our observations on L. loeselii at Lake Engure and also in other localities showed that dispersal of seeds by melting snow water is very important for populations in areas overgrowing with perennial herbs. Furthermore, the previous season capsules of $L$. loeselii were observed to remain till middle of next growing season and were not damaged by pathogenic fungi and bacteria. A part of the seeds remained in capsules and TTC test results showed that $>1 \%$ of these seeds had viable embryos and could germinate. This might be an adaptation that promotes population survival.

Rapid growth and mode of seed dispersal allows to characterise L. loeselii as a good coloniser, but it is a poor competitors. For example, at the Orchid Trail $\left(57^{\circ} 15^{\prime} 617 ; 23^{\circ}\right.$ 08' 681), two specimens of L. loeselii emerged in 2010 and 17 in 2011. The study of the annual cycles allows to develop recommendations for management of the species. In the investigated localities of $L$. loeselii it is necessary to ensure the conservation of the species. We suggest that there is a need to create suitable habitat corridors through areas with $C$. mariscus. Calcareous fens with $S$. ferrugineus and C. mariscus are a protected habitat in Latvia and Europe. This habitat needs special management, as it represents a stages of natural succession, but not the final step. In calcareous fens overgrown with $C$. mariscus, and where the habitat 7230 is a priority of conservation, C. mariscus can mowed to reduce its cover (Auniņš, 2010). This will provide an adequate light regime for the species and ensure better dispersal of seeds of $L$. loeselii with wind and snow melt waters.

The survival of $L$. loeselii as an early successional species in wet habitats with fluctuating water level is ensured by various adaptations. The bogging of the shore of Lake Engure creates new suitable habitats for L. loeselii as an early successional species. If we want to conserve the existing localities, management is required, which considering the annual cycle of L. loeselii, should be undertaken in February-March.

\section{ACKNOWLEDGEMENTS}

The Latvian Council of Science financed the project No. 09.1549 "Biological Plant Protection, Biodiversity Conservation and the Role of Plant Mineral Nutrition in Global Changing Environment ", part C "The Ecological and Biological Investigation of Wild Orchid Species as Basis for Biodiversity Conservation of Orchidaceae in Latvia". 
This work has been supported by the European Social Fund within the Project ,,Support for the Implementation of Doctoral Studies at Daugavpils University." Agreement Nr. 2009/0140/1DP/1.2.1.2/09/IPIA/VIAA/015.

The greatest thanks to Assoc. Prof. Voldemārs Spungis for entomological studies according to the projects of Latvian Council of Science Nos. 09.1295 and 09.1549.

\section{REFERENCES}

Andrushaitis, G. (ed.) (2003). Red Data Book of Latvia. Rare and Threatened Plants and Animals. Vol. 3. Riga: Institute of Biology of University of Latvia. $691 \mathrm{pp}$.

Arditti, J. (1992). Fundamentals of Orchid Biology. New York: John Wiley \& Sons. 691 pp.

Auniņš, A. (ed.) (2010). Eiropas Savienības aizsargājamie biotopi Latvijā. Noteikšanas rokasgrāmata [EU protected habitats in Latvia. A key]. Rīga: Latvijas Dabas fonds. 319 1pp. (in Latvian).

Ābolina, A. (2001). Latvijas sūnu saraksts [List of Latvian mosses]. Latvijas Veǵetācija, 4, 47-87 (in Latvian).

Braune, W., Leman, A., Taubert, H. (1999). Pflanzenanatomisches Praktikum I. Berlin: Spektrum Akademischer Verlag Heidelberg. 368 S.

Brižs, J. (2011). Dynamics of emergent macrophytes for 50 years in the coastal Lake Engure, Latvia. Proc. Latvian Acad Sci, Section B, 65 (5/6), $170-177$.

Cepurīte, B. (2005). Latvijas vaskulāro augu flora 7: Orhideju dzimta (Orchidaceae) [Vascular Flora in Latvia, 7. Orchid Family (Orchidaceae). Rīga: Latvijas Universitāte. 74 lpp.

Cronk, J., Fennesy, M. (2001). Wetland Plants. Biology and Ecology. Florida: Lewis Publishers Boca Raton. 462 pp.

Jersakova, J., Kinndlman, P. (2004). Reproductive success and sex variation in nectarless and rewarding orchids. Int. J. Plant Sci., 165, 779-785.

Justin, S. H. F. W., Armstrong, W. (1987). The anatomical characteristics of roots and plant response to soil flooding. New Phytol., 106, 465-495.

Kabucis, I., Račinska, I., Pozņaka, L. (2004). Engures ezera dabas parka dabas aizsardzības plāna ieviešana [Implementation of the Management of the Lake Engure Nature Park]. Rīga: Latvijas Dabas fonds. 16 1pp. (in Latvian).

Kḷavin̄š, M., Kokorīte, I., Rodinovs, V. (2013). Engures ezera ūdenu sastāvs un to ietekmējošie faktori [Water content of Lake Engure and the factors influencing it]. Melecis, V. (red.) Cilvēks un daba. Engures ekoreǵions (107.-120. lpp.). Rīga: LU Akadēmiskais apgāds.

Kull, T., Hutchings, M. (2006). A comparative analysis of decline in the distribution ranges of orchid species in Estonia and the United Kingdom. Biol. Conserv., 129 (1), 31-39.

Kull, T. (2013). Dynamics of orchid abundance in Europe. In: Proceedings of the $5^{\text {th }}$ International Orchid Workshop. Orchid Population Dynamics (p. 30). Rende: University of Calabria.

Kupffer, K. (1925). Grundzüge der Pflanzengeographie des Ostbaltischen Gebietes. Abhandlungen des Herder-Instituts zu Riga, 1 (6), I-V, 1-224.

Kurpniece, L., Latkovska, I., Apsīte, E. (2013). Klavinšs, M., Melecis, V. (red.) Engures ezera sateces baseina upju noteces ilgtermiņa izmaiņas 20. un 21. gadsimtā [Long-term changes of the Lake Engure catchment basin river runoff]. Grām.: Cilvēks un daba. Engures ekoreǵions. Rīga: LU Akadēmiskais apgāds. 91-96 lpp. (in Latvian).

Kuusk, V., Tabaka, L., Jankeviciene, R. (eds.) (2003). Flora of the Baltic Countries. Vol. 3. Tartu: Estonian Agricultural University. 405 pp

Laime, B. (2000). Seashore plant communities of the Lake Engures (Engure) Nature Park, Latvia. Proc. Latvian Acad. Sci. Sect. B, 5/6, 190-196.

Laiviņš, M., Rūsin̨a S., Medene A., Gavrilova G̣., Āboliṇa, A. (2012). Augāja stabilizācija Engures ezera sateces baseinā 1. Kalcifîtās augu sabiedrïbas [Vegetation stabilisation in Lake engure catchment basin. 1. Calciphyte plant communities]. Latvijas Veǵetācija, 23, 21-82 (in Latvian).

Mattrick, Ch. (2004). Liparis liliifolia (L.) L. C. Rich. ex Lindley Lily-leaved twayblade. New England Plant Conservation Program. Conservation and Research Plan for New England. Framingham: New England Wild Flower Society. $110 \mathrm{pp}$.

McMaster, R. (2001). Populations biology of Liparis loeselii, Loesel's twayblade, in a Massachusetts wetland. Northeastern Naturalist, 8 (2), $163-178$.

Moore, D. (1980). Liparis L. C. M. Richard. In: Tutin, T. G, Heywood, V. H., Burges, N. A., Moore, D. M., Valentine, D. H., Walters, S. M., Webb, D. A. (eds.). Flora Europaea, Vol. 5 (p. 350). Cambridge: Cambridge University Press, 452 pp.

Niklas, K. (1997). The Evolutionary Biology of Plants. Chicago and London: The University of Chicago Press. 449 pp.

Pakalne, M. (1994). Zāḷu purvu un ezeru krastmalu retās fitocenozes Baltijas jūras krastā (Latvija, Piejūras zemiene). Disertācijas kopsavilkums [Rare rich fen and lakeside communities of the Baltic coast. Doctoral thesis: summary]. Rìga. 34 1pp. (in Latvian).

Pakalne, M. (2008). Mire habitats and their protection. In: Pakalne, M. (ed.). Mire Conservation and Management in Especially Protected Nature Areas in Latvia. Rīga: Jelgava Printing House, pp. 8-19.

Pianka, E. (2000). Evolutionary Ecology. San-Francisco: Addison Wesley Educational Publishers. 512 pp.

Pillon, Y., Qamaruz-Zaman, F., Fay, M., Hendoux, F., Piquot, Y. (2007). Genetic diversity and ecological differentiation in the endangered fen orchid (Liparis loeselii). Conserv. Gen., 8, 177-184.

Ramsey M., Dixon K. (2003). Propagation science, recovery and translocation of terrestrial orchids. In: Dixon, K., Kell, K., Barrett, R., Cribb, P. (eds.). Orchid Conservation (pp. 259-288). Kotai Kinabulu, Sabah: Natural History Publications (Borneo).

Rasmussen, H. (1995). Terrestrial Orchids from Seed to Mycotrophic Plant. New York: Cambridge University Press. 444 pp.

Rolfsmeier, S. (2007). Liparis loeselii (L.) Rich. (yellow widelip orchid): technical conservation assesment. USDA Forest Service, Rocky Mountain Region.

http://www.fs.fed.us/r2/projects/scp/assessments/liparisloeselii.pdf (accessed 12.09.2013).

Roze, D., Jakobsone, G., Megre, D. (2013a). The growth characteristics and morphometric variations of Liparis loeselii leaves in different microhabitats. $7^{\text {th }}$ International Conference "Research and Conservation of Biological Diversity in Baltic Regions". Book of Abstracts (p. 90). Daugavpils: Daugavpils University Academic Press "Saule".

Roze, D., Megre, D., Jakobsone, G., Šmite, D. (2013b). Environmental influences and adaptations in annual cycles of Liparis loeselii. World Acad. Sci. Eng. Technol., 77, 1257.

Roze, D., Jakobsone, G., Megre, D., Kreile, V. Višnevska, L., Belogrudova, I. (2011) Possible ecological reasons for the threat of Liparis loeselii populations in Latvia - preliminary results. Proceedings of the $6^{\text {th }}$ Planta Europa Conference Actions for Wild Plants, Krakow, May 23-27. Krakow.

Ruzin, S. (1999). Plant Mictotechnique and Microscopy. New York: Oxford University Press. 322 pp.

Salmina, L. (2009). Limnogēno purvu veǵetācija Latvijā [Vegetation of limnogenous fens in Latvia]. Latvijas Veǵetācija, 19, 1-188 (in Latvian).

Scoggan, H. (1978). The Flora of Canada, Vol. 2. Ottawa: National Museum Natural Sciences Publications in Botany. 545 pp.

Sell, P., Murrell, G. (1996). Flora of Great Britain and Ireland. ButomaceaeOrcidaceae. Vol. 5. Cambridge: University Press. 410 pp.

Springe, G., Druvietis, I., Parele, E. (2000). The plankton and benthos communities of the lagoon lake Engures (Engure), Latvia. Proc. Latvian Acad. Sci. Sect. B, 5/6, 177-189. 
Van der Cingel, N. A. (2001). An Atlas of Orchid Pollination: America, Africa, Asia and Australia. Rotterdam: A. A. Balkema. 296 pp.

Vīksne, J. (1997). Engure - putnu ezers [Bird Lake Engure]. Rīga: Jāṇasēta, 111 lpp. (in Latvian).

Vìksne, J. (2000). Changes of nesting bird fauna at the Engure Ramsar site Latvia, during the last 50 years. Proc. Latvian Acad. Sci., Sect. B, 54 (5), 213-220.

Received 17 October 2013
Wheeler, B., Lambley, P., Geeson, J. (1998). Liparis loeselii (L.) Rich. in eastern England: Constraints on distribution and population development. Bot. J. Linnean Soc., 126 (1-2), 141-158.

Zviedre, E., Grīnberga, L. (2012). New species of Charophyta, Chara polyacantha A. Braun, in Lake Engure, Latvia. Biodivers. Res. Conserv., 25, 43-45.

Федоров А. А. (ред.). (1976). Флора европейской части СССР [Fedorov, A. A. Flora of the European part of the USSR]. Tом 22. Ленинград: Наука. 760 с. (in Russian).

\section{AGRĀS SUKCESIJAS SUGAS Liparis loeselii GADA CIKLA EKOLOG̣ISKĀS İPATNĪBAS SUGAS IZDZĪVOŠANAS IESPĒJU NODROŠINĀŠSNAI ENGURES EZERA APKĀRTNĒ}

Raksts iepazīstina ar pētījumu, kas sešu gadu garumā (2008-2013) veikts divās Liparis loeselii (L.) Rich. atradnēs Engures ezera apkārtnē. Pētījuma mērḳis bija noskaidrot, kā tipiska agrās sukcesijas suga spējusi šādā mainīgā vidē izdzīvot vairāk kā 100 gadus. Herbārija un gada cikla studijas lauka pētījumi atklāja, ka gada cikli ir līdzīgi un ka suga strauji nereağè uz klimata izmaiņām. Mūsu pētījuma rezultāti parādīja, ka L. loeselii izdzīvošanu mitros biotopos ar mainīgu ūdens līmeni nodrošina pielāgotību komplekss. Seklā sakṇu sistēma laaj pārciest īslaicīgu applūšanu. Lapas un ziedkopa attīstās jūnija sākumā; ja attīstība aizkavējas, lapas un ziedkopa sāk augt gandrīz vienlaicīgi. Sēklas nogatavojas ruden̄i, bet izsējas pavasarī un izplatās ar sniega kušanas ūdeniem, kas ir īpaši svarīgi populācijām, kuras atrodas aizaugošos biotopos. No iepriekšējās sezonas neatvērušajās pogạ̣ās palikušo sēklu embriju dzīvotspēja saglabājas zemāka par 1\%, kas, ņemot vērā orhidejām raksturīgo lielo sēklu skaitu, tomēr palielina populācijas izdzīvošanas iespējas. 